\title{
Hanseniaspora guilliermondii
}

National Cancer Institute

\section{Source}

National Cancer Institute. Hanseniaspora guilliermondii. NCI Thesaurus. Code C127717.

A species of apiculate yeast in the phylum Ascomycota that are found on dates, grapes, tomatoes, figs, and in soil. This species is only able to ferment glucose. 